\title{
Internet écl@ire
}

\author{
@@@ France@@@
}

@1. Fiche pratique radioprotection : retrait des détecteurs de fumée à chambre d'ionisation (DFCI) (INRS - Institut national de recherche et de sécurité)

http://www.inrs.fr/accueil/produits/mediatheque/doc/publications.html?

refINRS $=E D \% 204440$

@@@ Grandes agences@@@

@ 2. Ground deposition maps of Iodine 131 discharged from Fukushima Daiichi were produced using a newly developed method for analyzing airborne monitoring data- Joint study with JAEA and DOE/NNSA (JAEA - Japan Atomic Energy Agency)

http://www.jaea.go.jp/english/news/press/p13062701/index.html

@@@ À consulter également @ @ @

@3. Un compteur Geiger dans son smartphone (ADIT)

http://www.bulletins-electroniques.com/actualites/73210.htm

@@@ Rayonnements non-ionisants @ @ @

@ 4. A French study of childhood leukaemia and proximity to high-voltage power lines (EMF - Electric and Magnetic Fields)

Pour en savoir plus : http://www.emfs.info/The+Science/Research/france/

@5. An European electric and magnetic fields directive was published in the official journal (EMF - Electric and Magnetic Fields)

Pour en savoir plus : http://www.emfs.info/Related+Issues/limits/specific/EU2013/

[Dernières consultations des pages web le 18 juillet 2013].

Sandrine Figueiredo

IRSN

DOI: 10.1051/radiopro/2013093

RADIOPROTECTION - VOL. 48 - Nº 4 (2013) 